\title{
'Our Old Friends and Recent Foes': James Cowan, Rudall Hayward and Memories of Natural Affections in the New Zealand Wars
}

\section{ANNABEL COOPER}

When the First Taranaki War ended in 1861, a young settler and engineer called George Robinson celebrated the apparent end of interracial hostilities by venturing out with his fellow volunteers to rediscover a peach orchard that war had made inaccessible. Appetites satisfied, he and his friends were exploring further into the lately contested territory, when they met a 'lad' they knew from one of the resistant Māori settlements. The boy invited them home to where his people were now living: after some hesitation, they accompanied him. On the way they came across a fortification (pā), which Robinson investigated with an attentive engineer's eye. Sixty years later he wrote a detailed description of the pā for James Cowan, then collecting material for his official history of the New Zealand Wars. But Robinson's story did not stop there. It continued on to the soldier-settlers' arrival at the first of the settlements, Paraiti:

The Maoris were startled at our appearance, not knowing our numbers or how we came there, but our guide calling out the explanation, they rushed forward to welcome us in the good old Maori way, shouting, laughing, crying, all but embracing us. We stayed with them about half an hour, and then moved on and up the hill to a plateau, where we found the Ninia natives. A messenger having warned them of our approach, we received from them the same riotous welcome. After staying awhile we moved on to the Kaipakopako settlement, accompanied by a bodyguard of excitable chatty friends, and were again cordially welcomed by hundreds of our old friends and recent foes, who anxiously inquired as to who were killed or wounded amongst those they knew at Bell Block, and told us of their own fatalities. They showed no sign of rancour or ill feeling. I was talking to a chief when suddenly he opened the blanket he had around him and showed me his right arm: it had been shot through the elbow, the bone broken, and, being badly set, the arm had withered and was useless. He told me he was shot at Puketa-kauere, and on my saying I was present at that engagement he explained how he received his wound ... [While searching for wounded after the battle] he saw a sergeant lying wounded ... shooting all who came near. The chief bounded forward to tomahawk him, but received a bullet through his arm, and shouted for help. A number of Maoris came, and, first disabling the sergeant with gun-fire, they tomahawked him. The chief said the sergeant shot seven of the Maori who attacked him before he was killed.

As we had about eight miles to travel by the nearest route to get back to the Bell Block post, and as the sun was nearing the horizon, we had to say good-bye to our friends and hurry back, so as to get through the bush before dark. We reached the blockhouse before 9 p.m. in time to answer to our names at roll-call. ${ }^{1}$

The story moves rapidly between enmity and friendship, and across opposing emotional states. The soldiers are suspicious, but they trust their young guide; the Māori too are wary, but greet their old neighbours who, it should be noted, had benefited from a highly contentious land purchase, with warmth and joy. Everyone now wants to carry on the delight of the occasion, so the settlers are accompanied 
from one settlement to the next as the reunion becomes more and more joyous. The subject of the war is by no means avoided: news about the toll on each side is exchanged as the tragedy dividing them becomes a tragedy they share. In part, what seems to be happening here is that the Māori, well used to settling differences through armed conflict, convey to the settlers their assumption that although they were enemies yesterday, they are friends again today. Sixty years on, Robinson too sustains memories of both lethal enmity and warm affection.

The story mattered enough to Robinson that he included this coda to his account of the fortification in his letter to Cowan, and it was pertinent enough for Cowan to incorporate in his chapters on the First Taranaki War; even though the pā was peripheral (no engagement having taken place there), he included the entire letter in an appendix to his New Zealand Wars and the Pioneering Period (1922-1923). The letter was written at the point where living memory of the wars such as Robinson's was being overtaken by cultural memory. Indeed, Cowan came to be the most influential figure in determining the shape of Pākehā cultural memory of the wars in the first half of the twentieth century, challenged only by the filmmaker Rudall Hayward, whom he inspired and informed. This essay addresses the significance of Cowan and Hayward, and the distinctive cultural memory of colonial war which they helped to produce. In particular, it traces the persistence of the trope of 'natural affection' in their war narratives, across a variety of forms: quotidian interracial affection, military alliance and protection, the figures of the cultural go-between and the 'half-caste', and interracial romance and marriage.

It is my contention that the pasts the producers of these new wars stories wrote for their present were as much the work of a specific form of colonialism as the wars themselves had been. In asking what shape these new pasts took, I ask how far Cowan's and Hayward's interventions in cultural memory reflect historical realities of intermarriage, collaboration, friendship and proximity between Pākehā and Māori; or, conversely, to what extent they betray ongoing anxiety about colonial legacies among Pākehā New Zealanders intent on shaping their ethnic identity around ideals of fairness and natural justice. ${ }^{2}$

Interracial affection - in the forms or romance, friendship and alliance - crops up repeatedly in Pākehā New Zealanders' narratives of the colonial wars. Although at the national level the wars have still barely been memorialized, and indeed as Belich has argued may be the object of systematic amnesia, ${ }^{3}$ the implications of colonial conflict for the nation's conduct of race relations have frequently engaged the attention of an array of cultural producers of European as well as Māori descent. In a genealogy of these conflicts' place in Pākehā cultural memory, literary fiction and film demand as much attention as written histories. As Edward Said has argued, colonization proceeds not only through political and military institutions but cultural ones, including the dissemination and consumption of narrative fiction. ${ }^{4}$ This should lead us to adopt some skepticism towards narratives of affection in the midst of conflict; but to stop at skepticism, I will suggest, would be to underestimate how seriously some Pākehā cultural producers were engaging with difficult national legacies. Jacqueline Rose traces colonial histories through fictions poised at historical crossroads, demonstrating how they can open a line into the 'unconscious dreams of nations': such an approach is a potentially productive one in analysis of narratives of the New Zealand Wars. ${ }^{5}$ 


\section{Settlement, conflict and 'racial amalgamation'}

Several dimensions of the historical context undoubtedly contributed to the preoccupation with affection and intimacy. The first was the demographic pattern: the high rate of intermarriage in colonial New Zealand society. ${ }^{6}$ Intermarriage was frequent amongst the first European settlers, who were mainly men, and although it dropped towards the end of the nineteenth century, it remained high by the standards of settler societies. ${ }^{7}$ Families of mixed race were common in both Pākehā and Māori worlds, especially in rural areas. While communities, especially in the North Island, tended to remain relatively separate there was a significant degree of interaction between them. As the twentieth century proceeded, however, separation became more marked as Pākehā concentrated in urban centres some decades before Māori, so that, as Belich has noted, by the 1930s many urban Pākehā almost never had dealings with Māori, or rather, with people who identified as Māori. ${ }^{8}$ Those of mixed ancestry had interpenetrated both populations, and remained a demographic reality.

A second, related point is that New Zealand was Britain's last major colony and its settlement coincided with a marked endorsement of 'racial amalgamation' as the preferred strategy of colonization. ${ }^{9}$ The idea that 'one people' could be created over time, and Māori incorporated into European society including by intermarriage (but not the other way around), had both official endorsement and relatively wide popular purchase among settlers, although in reality most people of mixed ancestry, being the children of Māori mothers, grew up in and affiliated more with indigenous society. As Salesa has shown, the New Zealand Wars exposed the considerable diversity of concepts and domains within which people and families of mixed race were understood. By the 1860s there were many such people, and in the Waikato especially the wars generated competing claims on their affiliations and loyalties. ${ }^{10}$ At the ideological level, the nineteenth century ethos of 'racial amalgamation' undoubtedly had a place in the genealogy of the myth of racial harmony prevailing through much of the twentieth century.

A different colonial discourse, however, competed with 'racial amalgamation' at least until the first decades of the twentieth century. The 'dying race' trope, and its attendant, compensatory trope of interracial respect, gained a powerful impetus in an influential editorial written just days after the battle of Orākau towards the end of the Waikato War. ${ }^{11}$ Edward Fitzgerald gave Orākau enduring form in Pākehā cultural memory as the 'last stand' of a heroic people:

No human situation can be conceived more desperate or more hopeless their lands gone, their race melting away like snow before the sun, and now their own time come at last: with enemies surrounding them on all sides, and nothing but certain death staring them in the face this is the last answer which they give to a proposal of peace and surrender, 'Friends - this is the reply of the Maori: We will go on fighting for ever! For ever! For ever!' 12

Fitzgerald slated the colonial proponents of a war 'dictated by avarice and prosecuted for spoliation ... to destroy a race that we might dwell in their tents'. ${ }^{13}$ His condemnation however did not stop the emergence of a key element in the cultural memory of Orākau: the idea that this battle underpinned mutual interracial respect for each side's military skill and heroism. Further, until Cowan's official history, Orākau's symbolic significance in colonial memory obscured the attack on the adjacent settlement of Rangiaowhia, where women, children and elderly were sent for safety, but attacked anyway in a messy and uncontrolled conflict, an event which could not so readily sustain the narrative of mutual respect. ${ }^{14}$ The place of Orākau in 
Pākehā memory rested partly on the reassuring fact of colonial victory: the underside of the battle's reputation was its embodiment of the 'dying race' trope. By the second decade of the twentieth century, however, the 'dying race' myth itself was melting, in the sunshine of the census: once measured, it was clear that the Māori population, including the mixed population which identified as Māori, was rising. ${ }^{15}$

Third, the New Zealand Wars brought Māori and colonial combatants together and apart in many ways: as enemies of different kinds, and as allies. ${ }^{16}$ In each of the successive conflicts, Māori had fought on both sides, and as the wars continued, the numbers allied with imperial and colonial forces grew. 'Friendly' (kupapa) troops were frequently essential to colonial success, either because of their knowledge of the country and bush fighting, or the calibre of their warriors. As James Belich has shown, these Māori fought for their own reasons and saw themselves as allied with, rather than in the service of, European troops. As early as the 1840s Tamati Waka Nene saved the Empire's face in the Northern War, and by 1870 the Whanganui alliance with colonials against Tìtokowaru, and Rāpata Wahawaha's critical involvement in the campaign against Te Kooti, were as significant in creating interracial alliances as they were in engaging enemies. ${ }^{17}$

Fourth, by 1915 and 1916, Māori were fighting not against but alongside Pākehā in Gallipoli and France. Not all Māori enlisted: the Waikato tribes (iwi), which had suffered extensive land confiscations after the colonial wars, resisted especially vigorously. The iwi who had fought with the Crown in the nineteenth century were far more strongly represented in the newly formed Pioneer Battalion. ${ }^{18}$ It is of some interest that it was in the midst of the First World War that the government was persuaded to commission an official history of the New Zealand Wars. With these larger historical forces in mind, this essay investigates two critical figures in the cultural production of the wars in the early decades of the twentieth century: the historian James Cowan, and the filmmaker Rudall Hayward.

\section{A life in the contact zone: James Cowan}

By the time James Cowan began writing about the New Zealand Wars in earnest, there was already a raft of narratives incorporating cross-cultural affection as well as conflict. Fiction and journalism alike provide examples of Māori or 'half-caste' maidens rescued by soldiers, or cross-cultural childhood affections sustained through the conflicts, and admiring accounts of Māori bravery in battle. ${ }^{19}$ Nevertheless the quantity, prominence and broad distribution of Cowan's literary production, which included feature articles syndicated in several major dailies and the widely read Railways Magazine and New Zealand Times, collections of short non-fiction stories, and a series of historical works, made him one of the most influential writers on Māori subjects for over half-a-century as living memory of the wars receded. ${ }^{20}$ During a period in which cultural forgetting at times threatened to displace cultural memory, his influence on New Zealand Wars narratives was immense.

Cowan's life story informed his writing. His childhood was spent on a farm obtained through the confiscations that followed the Waikato War (1863-1864); not only that, the Cowan property occupied part of the battlefield of Orākau, which was for a century the most famous of the battles of the New Zealand Wars. Through his childhood on the border of the rohe potae, the territory still controlled by the resistant Māori of the Kingitanga, settlers lived on the alert and were prepared for defence or escape. His were childhood memories of a place where fathers drilled, and there were incidents when settlers were attacked. Māori mostly crossed the border for more peaceful purposes, however, and 'Maoris were more numerous than pakehas; many a 
savage-looking and tattooed warrior ... called in at the home from one or other of the large villages just over the border; and native labour was employed at times on the farms'. ${ }^{21}$

Like many rural Pākehā, Cowan became fluent in Māori as a child, and he began his life-long acquisition of stories of the wars from both Māori and Pākehā veterans. His own first encounters with memory of the wars, therefore, arose in contexts of affection, mutual interest and trust, from men who only a decade or so earlier posed a threat to neighbouring settlers. These early friendships with Māori men - a number of whom became key informants for his official history of the wars decades later - and his boyhood forays into cross-cultural historical practice defined Cowan's subsequent career. As a journalist writing about Māori subjects he travelled extensively and by choice often with Māori companions. By the time of his major work on the wars, furthermore, he had married his second wife Eileen Stowell. Both her parents were of part-Māori descent: her mother from Te Ati Awa in Taranaki, and her father, Henry Stowell or Hare Hongi, from Ngā Puhi. They maintained links to both iwi. Hare Hongi was a distinctively bicultural individual: he had a European education but had also spent a year learning from the tohunga Ngā Kuku Mumu; he worked as a surveyor, then an interpreter in the Native Department, and wrote extensively on Māori subjects for the Journal of the Polynesian Society. ${ }^{22}$

Cowan's writing about the wars varied quite substantially, in part reflecting his own relationships with his sources as well as prevailing colonial views. In order to illustrate this I will note several examples: first, the early accounts of the PākehāMāori Kimble Bent, then the sections on Orākau and the East Coast War, and finally the conclusion from his official history of the wars. The Adventures of Kimble Bent: A Wild Life in the New Zealand Bush 1911, originally published as a series of newspaper articles in 1906, was Cowan's first major publication on the subject of the New Zealand Wars, and a clue to his later work. ${ }^{23}$ Cowan's interviews with Bent, a mixed race native American deserter from the colonial forces who defected in the late 1860s, documented his life with Ngāti Ruanui and allegiance to the chief Tìtokowaru throughout and after Titokowaru's War in 1869-1870. Despite its emphasis on the discomforts and precariousness of Bent's life among resistant Māori who did not always trust him, and intermittent sections which draw on discourses of savagism and primitivism, the book traces the process of cultural encounter, as an outsider came to belong in a Māori world. By the standards of the time, it is a sympathetic account. Cowan supplemented Bent's narrative with testimony from the colonial side and from Māori who had also been followers of Tìtokowaru, anticipating his later practice of telling the wars from all sides. This early narrative of an intimate cross-cultural life is the more remarkable because Cowan's work is also strongly influenced by the history and fiction of the North American West, where natural intimacies between colonizer and colonized were hardly a dominant theme. Indeed, if the frontier worlds of Frederic Jackson Turner, whose work Cowan read and admired, was dominated by westward-rolling economic change, the border society Cowan produced was much more strongly marked by the working out of cultural exchange in landscapes that were frequently both contested and shared.

\section{Childhood home and battlefield: Orākau}

The account of Orākau in The New Zealand Wars was inevitably a heavily freighted account. Fitzgerald's editorial had ensured that the battle was renowned even when the Cowan family settled there. Despite Fitzgerald's critical stance, the heroic defence led by Rewi Maniapoto had been quickly if paradoxically incorporated in Pākehā 
memory as a symbolic national event in which Pākehā respect for Māori 'unified' Māori and Pākehā. But it had a personal significance for someone who had a childhood attachment to the site. The way that Cowan wrote about it was remarkable, combining a deep affection for place with a historical consciousness of its past and recognition that others had also been attached to it: 'the village of Orākau "the Place of Trees" lay among its fruit-groves and its cultivated fields, gently tilted to the quarter of greatest sunshine', he opens, continuing:

Orakau was an idyllic home for the Maori. Like Rangiaowhia, it was a garden of fruit and root crops. On its slopes were groves of peaches, almonds, apples, quinces, and cherries; grape-vines climbed the trees and the thatched raupo houses. Potatoes, kumara, maize, melons, pumpkins, and vegetablemarrows were grown plentifully. Good crops of wheat were grown in the 'fifties' and early 'sixties'... . The Maoris at one time were paid 12s. a bushel for the wheat from Rangiaowhia and Orakau. "Ah," said old Tu Takerei, of Parawera, who was born in Orakau, "it was indeed a beautiful and fruitful place before the war. The food we grew was good and abundant, and the people were strong and healthy - there was no disease among them; those were the days of peace, when men and women died only of extreme old age". ${ }^{24}$

Cowan evokes here a specifically colonial peace, in which Māori benefit from introduced crops and agricultural practices, and acquire wealth through trade. But this was before the war: that prelapsarian time of peace and plenty has now gone, and the land confiscated. This ability to reflect on the complexity of his own attachment to Orākau recurs in his regional history of the Waipa, where he recounts the presence across the border, during his childhood, of 'the hundreds of Waikato dispossessed of their good lands on which we pakeha families now dwelt'. ${ }^{25}$

In the 40 pages of his two chapters on the battle, only about six are drawn from soldiers' records on the government side. The Orākau chapters are primarily records of a patriotic defence, recording meetings and the histories of mutual obligation among the defending iwi, the parts played by particular individuals primarily from the defending side, and songs, dreams and prayers which constituted the Māori interpretative legacy of the battle. As the chapters proceed, first person accounts are increasingly prioritized, and with the exception of the government negotiator William Mair, whose account is presented in a smaller font and in this way distinguished from the main narrative, Cowan's primary informants were Te Huia Raureti, Hitiri te Paerata and Tupotahi, whose photographs are all included in the chapters; it is very likely that he had known them since childhood. The breakout from the pā - the climactic event of the battle - culminates in a page-long first person account by Rewi Maniapoto himself, recorded at Orākau: if Cowan did indeed record this himself, it is testimony to his avid collection of narratives about the battle even as a young man, as Rewi died when Cowan was about 24 years old. ${ }^{26}$ While the chapters do take up elements of the Pākehā mythologizing, they are nevertheless constituted through Cowan's own relationships with the veteran defenders of Orākau, and he sees the battle primarily from their point of view.

If Cowan's own intimacies facilitated the centrality of the defenders' narratives, the accounts drawn from colonial soldiers also differentiate them from 'the imperials', the British. He believed that the wars had forged a relationship of mutual respect between Māori and Pākehā, and Orākau was a central component of this prevalent view. More recent, critical accounts have argued that many of those killed 
during the retreat and the attack on the pā were women and children. Cowan does not go this far. While he gives a great deal of detail about the slaughter involved in the retreat, his interspersing of colonial accounts incorporates them into the larger narrative of interracial respect. He quotes a colonel in the Forest Rangers who tells a story which had already gained fame, in which a defender repeatedly stopped and aimed his gun at the following troops to cover retreating wounded but did not fire. 'At last one of us shot him dead. We went up to the plucky fellow as he lay there in the rushes, and we found that his gun was empty; he had not a single cartridge left. ... I was terribly grieved - we all were - to think that we had killed so brave a man'. ${ }^{27}$

Another account differentiates between the behaviour of colonial and British soldiers. The process of including this account offers Cowan the opportunity to individualize the Māori women in the pā, to name and recount the standing of one woman, and to introduce the various kinds of interracial family ties which the war had cut across. Colonial soldiers, Cowan implies, know and respect these affiliations but imperial soldiers do not:

Among the wounded were several women, and even these did not escape the bayonets of the maddened Imperials. The colonial troops behaved better. In the flight to the Puniu a half-cast girl, shot through the arm, was on the point of being bayoneted by a soldier when a Forest Ranger saved her; and Von Tempsky's favourite scout, Sergeant Southee, protected another. In the $p a$, however, there was a pitiful tragedy. Mr Mair, rushing in with the stormers, found some Regulars about to bayonet a wounded woman who had scraped away the light layer of earth covering the body of her slain husband for a last look at him, weeping as she brushed the soil from his face. Mair tried to beat the men back with his carbine, and knocked one of them into the ditch; then he turned to attend to the poor woman. She was Hine-i-turama, a high chieftainess of the Arawa people, ninth in direct descent from Hinemoa, and celebrated as a composer of songs; she had been the wife of Hans Tapsel, the trader of Maketu, and on coming to Orakau to visit her daughter, the wife of Dr. Hooper ... married another man, Ropata, who fell in the siege. Mr. Mair carried her to an angle, and then went to attend to another wounded woman; but when he returned Hine-i-turama had been bayoneted to death by some brutal soldiers in avengement of fallen comrades. ${ }^{28}$

This paragraph's distinction between colonials and imperials is underpinned by Cowan's commitment to 'natural affections'. Thus the imperials are brutal and vengeful, whereas the colonial soldiers - in recognition of the presence of women, but also, perhaps, in allegiance to older, cross-cultural, attachments - are suddenly ready not to attack but to defend.

\section{Enemies and allies: the Te Kooti campaign}

Cowan's accounts of resistant Māori are much less sympathetic in the second volume of The New Zealand Wars than they had been in the first. In particular, Cowan's account of the pursuit of the warrior prophet Te Kooti has a sharply critical character. Here again he follows prevailing Pākehā opinion: Te Kooti had been a favoured bogeyman for decades. In sharp contrast to the chapters on Orākau, there are almost no narratives from Te Kooti's side. It is possible that followers of Te Kooti were more reluctant than the old Waikato warriors (toa) had been, to entrust Cowan with their 
accounts. The main exception is the account of Peita Kotuku, who fought with Te Kooti but who was from Ngāti Maniapoto in the Waikato, and might therefore have had more reason to know and trust Cowan. Mostly, the first hand narratives of the pursuit of Te Kooti come from the government side, principally from Mair, Preece and Porter, officers who were involved in the unsuccessful pursuit of Te Kooti over three years.

Cowan had little time for the millennialist Christianity of the later period of the wars, and he believed Te Kooti to be a charlatan in his claim to prophesy, as well as a tyrannical and manipulative leader. Rather than an account of heroic defeat, his is a story of dashing but frustrated pursuit, against an elusive, agile enemy, and it is told almost entirely from the pursuers' point of view. The story is recognizable as imperial adventure in a way that the account of Orākau is not, and yet it is also unusual because the majority of the troops who pursued Te Kooti were 'friendlies' - Ngāti Porou, Ngāti Kahungungu and Te Arawa contingents who fought with colonial troops, with a mix of Māori and colonial leadership. So if the account of Orākau marks Cowan's own affectionate relationship with his old Waikato veterans - the narrative itself a sign that the fighting is over and mutual affection is now restored - the equivalent cross-cultural bonds in Cowan's account of the east coast are those between the colonial soldiers and their Māori allies. Rāpata Wahawaha's relationships with Preece and Porter, particularly, stand out; it is not difficult to imagine, in the account of Rāpata and Preece firing along a trench at Ngātapa, that many of Cowan's contemporary readers would have found in it an echo of recent events at Gallipoli. ${ }^{29}$ These bonds, however, are less emphatically registered in the narrative than the divisions among Māori, who were themselves engaged in a protracted civil war on the east coast unlike anything that occurred in the Waikato.

Cowan's conclusion to the volume situates cultural memory of the nineteenthcentury wars within a more immediate context, finding the opportunity to put interracial conflict firmly in the past while asserting its legacy as a unifying one:

Pakeha and Maori are now knit in such close bonds of friendship that they can contemplate without a trace of the olden enmities the long-drawn struggles of other years, and find a mutual satisfaction in the thought that the military traditions of the pioneer period have left appreciable lasting impression on the New Zealand national type. One thing only was needed to cement for ever the union of the races, and that opportunity the Great War brought. Maori soldiers fought and died by the side of their pakeha fellowNew Zealanders .... So in the greatest of all wars the Maori of the young generation proved his warrior worth, and showed the world that the heroic spirit and the quality of endurance which won the grim defenders of Orakau a deathless fame have not deserted the sons of the ancient fighting-race. ${ }^{30}$

\section{Romance in the local western: Rudall Hayward}

Cowan's official history was both source and inspiration for a number of novelists and film-makers in subsequent decades. ${ }^{31}$ The first of them, the New Zealand film pioneer Rudall Hayward, quickly saw the potential of the New Zealand Wars for adventure, romance, and nation-making in which forms of interracial intimacy were central. Hayward was a consummately pragmatic film-maker with a sure instinct for the box office. Bruce Babington points out that although he drew directly from Cowan's official history, it was The Adventures of Kimble Bent 'with its anti-hero deserting to a Māori tribe, and its racially muddled lines of battle' which first drew his interest, and 'suggests his films' complicated cross-empathies'. ${ }^{32}$ Hayward made three 
films about the wars: two silent films, Rewi's Last Stand 1925 (of which only fragments and a plot summary survive), The Te Kooti Trail 1927, and a sound version of Rewi's Last Stand 1940. Less a remake than a different film, with a different scenario, from the silent version, the second Rewi does not survive in anything like its entirety as the extant version is a re-cut, greatly shortened film made for release in Britain as The Last Stand. ${ }^{33}$ Hayward was a resourceful and talented film-maker and publicist: all three of his New Zealand Wars films were media events which attracted broad public attention. Interracial intimacy was the basis for at least one plot element in all three films, and Hayward's successive negotiations with the tribal groups whose histories were enacted are also worth our attention as interracial engagements.

In the surviving first reel of the silent Rewi's Last Stand, and from the plot summary in the film's press kit, it appears that an incipient interracial romance forms part of the plot, which derives as much from Victorian fictional plots as from historical sources. The Pākehā hero Kenneth Gordon has fallen in love with a white girl, Cecily Wake, before enlisting with the Forest Rangers and heading off to fight in the Waikato War, but during the war he is thrown together with Takiri, a 'Maori maiden of high birth'. Both are captured and Ken is imprisoned; eventually he is brought before Rewi Maniapoto on the eve of the battle of Orākau. When 'finally the Maoris make their glorious dash for freedom' from the besieged pā, Ken is liberated and endeavours, with Takiri, to regain the British lines, but Takiri is shot and dies in Ken's arms. Ken is eventually reunited with Cecily. ${ }^{34}$ This version of Rewi's Last Stand dramatizes a cross-cultural alliance across opposing lines, but the death of Takiri offers the alliance no future: only the Pākehā couple survive.

Hayward anchored the next film, The Te Kooti Trail 1927, much more closely in Cowan's historical work. Natural affections between 'friendly' Māori and Pākehā characters, and alliances between Māori and Pākehā against Te Kooti form the basis of the plot, which draws in detail on incidents from Cowan's accounts. ${ }^{35}$ The historical individuals and incidents conflated to create the film's plot provide for the dramatization of several interracial relationships. The French miller Jean Guerrin and his Māori wife Erihapeti enact successful interracial collaboration in agricultural productivity and domestic happiness. When Te Kooti attacks the 'friendly' Ngāti Pukeko, Jean bravely organizes the defence, and he and Erihapeti's sister Monika conceal a cache of ammunition. Other Pākehā allies include the well-known colonial soldier Gilbert Mair and a fictional comic trio of foot soldiers who engage in crossracial jollity with Māori in comic scenes. Alarms are raised as Te Kooti's warriors descend, firing their guns and galloping horses down hillsides and across broad sweeps of plain: Hayward was well attuned to the market for a local Western. Compressing events to include a related incident at Rauporoa pā, Hayward dispatches Monika's lover Taranahi to summon the assistance of Gilbert Mair, and Mair's famous ride down the coast to raise a neighbouring Māori force is enacted. Affiliations are dramatized, then, on two levels. First, Jean and Erihapeti conduct a loving marriage, and the mise-en-scene repeatedly situates Māori and Pākehā in easy, affectionate interaction. Footage of grain harvesting and milling underpins a theme of collaborative agricultural productivity, involving Māori adoption and use of European crops, that carries through from Cowan as a resonant symbol of the pre-war period. Second, the plot selects and harnesses historical events on the east coast to facilitate a narrative of alliance between colonials and 'friendly' Māori against hostile or 'fanatical' Māori, an alliance made personal through the bonds between Mair and Taranahi, and Guerrin and Monika. 
The climax of the film and its pathos are concentrated in the enmities among Māori, in scenes which do not include Pākehā. Cowan's account of the capture and protection of Erihapeti and Monika by Te Rangihiroa, one of Te Kooti's captains, Monika's refusal to betray the location of the ammunition, and Te Kooti's directive that all three be punished by having Te Rangihiroa kill Monika and marry the newly widowed Erihapeti, is enacted with one substantial modification. In the film it is not Te Kooti but his lieutenant, Baker McLean/Peka Makarini, who concocts this cruel field sentence.

This change to Cowan's account has attracted commentary pertinent to my discussion, relating particularly to the identification in the intertitles of Peka Makarini as a 'half-caste' and the malevolent cruelty attributed to him in the film. Does the displacement of the film's cruellest act from Te Kooti to Peka level the charge at mixed race, as some critics have thought? If so, The Te Kooti Trail would seem to sit at odds with the cultural purchase of 'racial amalgamation' and the broader absence of cultural anxiety over miscegenation between Pākehā and Māori. Martin Blythe first suggested that, despite an emergent tradition of cross-cultural romance in New Zealand film, The Te Kooti Trail appears to echo D.W. Griffith's Birth of a Nation in its condemnation of miscegenation. Alistair Fox adopts a similar stance in a more recent analysis. ${ }^{36}$ Blythe qualified this view however by noting that if the 'half-caste' was demonized in the figure of Peka, the interracial marriage of Erihapeti and Jean was lauded. Perhaps, he suggests, Peka represented 'the unacceptable face of union between Maori and Pakeha - unacceptable when the half-caste identifies with Maori nationalism'. ${ }^{37}$ Diane Pivac and Bruce Babington have both pursued this reservation. They observe that Hayward's concern may not have been Peka but Te Kooti: he had reason to tread cautiously around Te Kooti's reputation given that Ringatū elders were keeping a close eye on how he portrayed the founder of their religion. ${ }^{38}$ The film was made around Whakatane in the Bay of Plenty, in a region where many Māori belonged to the Ringatū church. Further, as Babington notes, despite Hayward's admiration for Griffith, 'nothing is made of [Peka's] mixed race as Hayward steers clear of the fears played upon in Birth of a Nation ... it is as if Hayward, propelled by his admiration for Griffith into a region of unfamiliarly extreme attitudes, backs off, finding his mentor's beliefs less admirable than his aesthetics' ${ }^{39}$

It should be noted, too, that despite the transfer of responsibility for Monika's murder from Te Kooti to Peka Makarini, the film's portrayal of each of them remains very consistent with Cowan's. Cowan frequently describes Peka as 'half-caste', but he uses the term neutrally and with little sense that Peka's brutality is linked to his ancestry. Cowan also attached 'half-caste' as a descriptor to individuals he plainly admired, such as Pou-patate. ${ }^{40}$ It is likely, therefore, that Peka's record rather than his mixed ancestry marked him out for Hayward as an available villain. In a further reattribution, Hayward makes Taranahi, Monika's fictional lover, responsible for Peka's own death. Wounded and dying, Taranahi avenges Monika and protects Mair as his last shot kills Peka, endorsing the commitments of 'friendly' Māori to tribe and colonial allies alike.

\section{Film-maker and iwi}

At this juncture it is worth turning to Hayward's own interracial negotiations through the production of his three New Zealand Wars films. ${ }^{41}$ As Diane Pivac has shown, he began badly but developed a degree of cultural literacy as he went on. In preparation for the silent Rewi he approached Te Puea Herangi, then the most influential figure of the Waikato iwi, in his first attempt to cast the Māori parts. His description of the 
negotiation reveals a degree of cultural knowledge - he knew what he should have done - overridden by impatience:

We wanted to use the Waikato Maoris because, of course, the Waikatos figured largely in the original historical incident and I went to Princess Te Puea and told her that I wanted to use Waikato Maoris in the film. I didn't want to use Arawas from Rotorua and I pleaded with her to organize for me a group of Maoris who would be suitable to play the part of the heroic defenders of Orākau Pa. I went to Ngāruawahia and I spent two days waiting round and listening to the Maoris discussing what would happen and eventually Princess Te Puea came to light with a proposition in which she wanted $£ 2,000$ in cash, a carved meeting house and a carved gateway. I had $£ 1,700$ to make the entire film so contrary to the usual methods I didn't stop to bargain - which I should have done - I should have waited and bargained but I didn't and because of that Princess Te Puea never forgave me. I went to Rotorua and used the Arawas, and that was the most terrible sin of all. She never forgave me for twenty years. ${ }^{42}$

He made further blunders on The Te Kooti Trail. Ringatū elders asked for a copy of the film's scenario. Hayward promised to provide it but as the film's release approached he evaded their requests. The elders then used their considerable political influence, and the film's release was held up by the government censor while they viewed it. They asked for the deletion of two intertitles, both attacking Te Kooti's reputation as a prophet. The requirements for release were the removal of the phrases 'resorting to faked miracles', and Peka as Te Kooti's 'torture master' and 'stage manager of miracles' ${ }^{43}$ Publicist that he was, Hayward turned the delay to market advantage, taking aim at Māori 'superstition' as he did so. ${ }^{44}$

In 1937, with an eye to the nation's approaching centenary year in 1940, Hayward began working towards remaking Rewi with sound: 'on the second occasion I was determined to try and make the film more accurate and to go to the Waikatos and to make it with the Waikatos, if it was possible.' ${ }^{45} \mathrm{He}$ approached the Te Awamutu Historical Society, 'a very live historical society', whose members formed Frontier Films to fund the new film. Although the descendants of settlers apparently outnumbered its Māori members, ${ }^{46}$ the Historical Society had been founded in a spirit of intercultural collaboration and had instituted cross-cultural research practices. Its most prominent Māori member was Raureti Te Huia, who was the son of Te Huia Raureti, a nephew of Rewi Maniapoto and Cowan's most important informant on the battle of Orākau. Raureti Te Huia was central to the Society's practice of local history: he always visited sites or elderly Māori in the company of Pākehā amateur historians, to provide Māori knowledge of places or as an interviewer. Within the limits of the time, the Society made considerable efforts to understand past and place from Māori as well as Pākehā perspectives. ${ }^{47}$

Hayward therefore drew on tribal cultural memory for the second Rewi, perhaps directly to a certain extent, but certainly through the cross-cultural practices of the Historical Society and perhaps through the Māori membership of Frontier Films, although he appears to have seen the supply of Māori actors as his key concern. ${ }^{48}$ One report asserts that some of the extras were played by boys from a juvenile detention centre, 'out for a day of exceptional fun', but considered attention was paid to casting the lead roles. Raureti Te Huia himself played the part of Rewi: he was related to Rewi and with his slight figure and aristocratic bearing he also resembled him. Another key part, the fictional Tama Te Heuheu, was played by Te Rongonui Paerata, 
a descendant of Te Paerata and Hitiri Te Paerata, other leading figures in the defence of Orākau (Hitiri Te Paerata was another of Cowan's sources). These descendants would inevitably have gained their knowledge about Orākau through oral transmission, from people who had themselves been there. The breadth of historical information potentially available to Hayward through this cultural engagement, therefore, was extremely rich: not only Cowan's histories, already extensively informed by participants on both sides, and the research of the Historical Society, but also the historical memory of several of the iwi involved. Exactly and how extensively he drew on the range of these sources, however, is much more difficult to determine; how well he dealt with the many Māori who participated in the film is also in some doubt. ${ }^{49}$

Another interracial intimacy developed over the course of the production. The part of the new heroine Ariana was played by an Auckland photographer of Irish and Māori descent, Ramai Te Miha. During the making of the film she and Hayward fell in love, replicating in real-life the interracial romance depicted onscreen. In 1943 Hayward divorced his first wife to marry Ramai, and they made films together until his death. A remarkably talented individual, Ramai did more than act in the film: for example, she drew the well-known film poster which shows a defiant warrior proclaiming the refusal to surrender. As a photographer, and given the small scale of the production and the fact that she went on to make films (she was the first Māori film-maker), it is possible that she also had some involvement in the shooting.

\section{The second Rewi: racial conflict and the 'half-caste'}

The Last Stand 1940, more commonly known by the name of the longer version Rewi's Last Stand, is the best-known of New Zealand's early feature films. Once again, Hayward wove interracial melodrama through a western narrative drawn from local events. In this film, however, Hayward situated the action much more precisely within the complex 'racial crossings' which particularly characterized the Waikato War, adopted a new historical source for his interracial romance, and - apparently drew on his local informants for a more detailed account of historical events. In describing the action of the film, he noted that 'As far as the history was concerned this time we tackled it from the point of view of what was happening in Te Awamutu and Kihikihi just prior to the Waikato War'. ${ }^{50}$ These place names are significant: Te Awamutu was the centre of the Anglican Mission, while Kihikihi was the base of the Ngāti Maniapoto leadership. Indeed the film repeatedly crosses battle lines. In this interview, Hayward went on to give an account of the historical setting which reveals his familiarity with the interracial affiliations of pre-War Waikato.

The plot centres on the position of the 'half-caste' as a dilemma in the context of racial conflict, as Martin Blythe has shown. In the Waikato War, this dilemma had a locally well-known historical basis, with members of interracial families aligned on different sides. While this narrative element drew on Cowan's writing, as I show below, it also had broad and ongoing local resonance. ${ }^{51}$ Stories of interracial families during the war would have been readily available to Hayward from people - Māori, Pākehā and mixed race - living in the locality. ${ }^{52}$ The new heroine Ariana and her backstory as a 'half-caste' child educated in the mission school at Te Awamutu drew on two historical threads. The historical Ariana first emerged in a comic news story published in 1864 and later retold several times by Cowan. A 'pretty half-caste girl', child of a Māori woman and a long-gone Englishman, she had been living with a settler family but when war broke out was 'carried off by rebels'. Ariana was wounded in the defence of Orākau but was protected by 'some brave fellow [who] 
stood over her and defended her life'. ${ }^{53}$ Once the story - and her beauty - became known a number of soldiers came forward to claim credit and to make a bid for her affections. As Hayward noted, 'One was particularly persistent ... (but) the young girl completely denied him. Well that didn't make good film material so I didn't use it but that was the basis for the character'. ${ }^{54}$ As played by Ramai Te Miha, the performance and filming of Ariana is shaped by contemporary Hollywood melodrama: breathless, passionate, gazing up adoringly at the hero, and torn between her Pākehā and Māori allegiance, the character has come some distance from the historical Ariana denying Pākehā lovers, and cross-cultural romance forms the core of the plot.

The second historical thread of Ariana's backstory involved John Morgan's Church Missionary Society settlement at Te Awamutu, a model of successful 'racial amalgamation', with Māori cultivation of European crops and a flourishing trade supplying Europeans, Māori adoption of Christianity, intermarriage consolidating a mixed race population, and a 'Half Caste School' which had around 40 children during the 1850s. ${ }^{55}$ Morgan was also, however, a key source of government information about Waikato Māori activity in the pre-war period. When the Waikato was invaded in 1863 and Morgan departed, the locality's production was quickly turned to support of the defence. Members of mixed race families were either kept within its aegis or expelled, depending on their perceived loyalty. ${ }^{56}$

In the film, the character Ariana has been brought up in Morgan's mission. In the lead up to hostilities she is keen to leave with the departing missionaries but the Ngāti Maniapoto are known to be claiming 'half-castes'. The trader hero Bob Beaumont - the model of a good colonist with his fluency in Māori - arranges to smuggle her out. Romance blossoms but Bob and Ariana are discovered on the journey by the warrior Tama Te Heuheu. At this point we learn of Bob's bicultural childhood: confronted by Tama, he proposes they fight with the taiaha. 'What know you of weapons?' asks Tama. 'I spent my boyhood in the far north, amongst your ancient friends, the Ngāpuhi', says Bob. 'Yes, I am a Ngāpuhi. We opened our veins ... our blood ran as one'. And although Bob loses the fight, he performs quite well enough with the taiaha to assert himself as a cross-cultural figure. ${ }^{57}$ Ariana is seized and taken back to the Maniapoto. Later, Bob, who has now enlisted with the Forest Rangers, encounters her again and offers the chance of escape, but this time she asserts her Māori ancestry: 'Maori women fight with their men.' Later, at the siege of Orākau, the film's climactic event, Bob and the old soldier Ben, whom we now know is Ariana's father, see her across the trenches among the defenders. A long battle sequence follows, in which each side demonstrates bravery and heroism, and colonial soldiers express their admiration for Māori courage: 'What glory can there be in killing men like these?' Interracial conflict and interracial intimacy now contend as a brutal bombardment is followed by attacks which leave many dead, and defenders fall wounded and dying during the breakout and retreat from the pāa, but Ariana's lover and her father make it their task to reach and rescue her. She is first protected by Tama. He dies covering her retreat, despite having run out of ammunition, Hayward here taking up the story of the heroic warrior turning to fire with an empty gun. When Bob and Ben find Ariana she is wounded. The film's two interracial romances converge as she is reunited with Bob, and realizes Ben is her father. The conclusion of the film as it survives suffers from the re-cutting done for the British release, but Ariana apparently dies in the final moments. ${ }^{58}$ While the conflict is one enacted between Ariana's dual inheritance, it is not her mixedness which the film posits as inherently problematic: rather, the anomaly is racial conflict, which confronts the romantic heroine with impossible loyalties and brings about her death. 
Despite the ending of the film, a somewhat loosely connected novelization written by A.W. Reed and published in the year before the film's release shows Bob and Ariana happily married at the end. Not only does Ariana, like her historical source, survive in the novel, she looks forward to a particularly prosperous future because both Bob and Ben are awarded sizeable grants of land after the war; and Ben donates his to the young couple as a wedding present. Her enthusiasm for what can only have been confiscated land betrays no reflection on the origin of the new wealth. ${ }^{59}$ The novelization, a device of Hayward's energetic publicity machine (Hayward appears not to have written it himself though his name appears with Reed's), provided a certain amount of backstory for his audience, yet in its departure from the film's plot and outcome it also introduces quite significant ambiguity around Hayward's stance. Did he waver over how he might end the film? There is no other evidence to confirm this, but the ambiguity may point more broadly to irresolvable problems for Pākehā cultural producers mythologizing Orākau as a site upon which 'interracial respect' was forged and the 'blended race' enabled. Was Orākau a heroic defence in which the nobility of each side was displayed, laying the ground for mutual respect, future reconciliation and eventual, happy conjugality? Or did the desperation of the defenders, the carnage, especially the killing of women and children, and the other incidents of this phase of the Waikato War such as the attack on Rangiaowhia, make it complex indeed for those who pushed past the myth to engage fully with the historical traces and the divergent cultural memories of this event?

\section{Conclusion}

By 1940, the last British colony's public and popular narratives of its colonial wars had a highly specific character, which though shaped initially by a diverse collection of journalism, soldiers' histories and adventure fiction, was increasingly dominated by high profile practitioners in two media: an official historian who, notwithstanding his liking for adventure narratives and excursions into discourses of savagism and primitivism, had a long standing commitment to an idea of the nation as a harmonious blending of two peoples, and accorded considerable recognition to Māori histories and perspectives; and a filmmaker who saw the potential of the Western and the melodrama as a vehicle for popularizing such a national story.

In the early interwar years, Cowan and Hayward were key figures in developing and promoting a Pākehā public memory of the wars which situated conflict between Māori and Pākehā as anomalous, affection as natural, and racial mixing as a national aspiration. Both were fascinated by the North American frontier, its fiction and film, and stated explicitly their desire for historical dramas played out in the New Zealand landscape - to show that New Zealand history was as exciting as America's. But although echoes of manifest destiny sound in their work - Cowan influenced by Frederick Jackson Turner, and Hayward by D.W. Griffiths - neither was willing simply to map the dominant narratives of North American western expansion on to the New Zealand past: they portrayed the wars not as the means of colonization, but dramatic interruptions to an otherwise amicable settlement where two peoples lived and worked together, and married each other. First Cowan, and later Hayward, had a personal commitment created with a second marriage to a woman of mixed race who identified as Māori. These perspectives were to varying degrees sustained in other historical and fictional narratives: William Pember Reeves, William Satchell, Mona Tracey and others also contributed to the cumulative iteration of the narrative in which natural affections mitigated the legacy of conflict. ${ }^{60}$ While there were selfserving Pākehā and 'fanatical' Māori in these narratives, they were persistently 
situated on the periphery, outside a circle of affection in which a new culture was created from two peoples who saw their futures aligned and increasingly united. ${ }^{61}$ Such narratives clearly had an historical antecedent in the policy and practice of 'racial amalgamation'.

In the cultural production of interracial affection, the prevalence of emotion masks the economic and military implications of interracial marriage and mixed ancestry. As Judith Binney and Angela Wanhalla have shown, property rights followed Māori women who married Pākehā men; and the ability of racially mixed men and women like James Edwards, John Gage and Lucy Takiora to cross enemy lines made them valuable government agents in some cases. ${ }^{62}$ In Hayward's films, these material and strategic dimensions of 'in-between lives' take second place to the affective dimensions. Ariana is played and filmed as a heroine of melodrama. As the men of both sides contend for her, she responds with emotions: romantic love, loyalty, the bonds of 'what is in me'.

One question here then, given the consistency with which 'natural affection' appears in stories and histories of colonial conflict through this period, is whether and to what extent the narrative repetition of interracial affections operated to discursively efface the receding but still recent spectre of colonial conflict. ${ }^{63}$ The Pākehā cultural producers discussed here were often sympathetic to Māori resistance and cognizant of the injustices perpetrated in the service of colonization, but they were nevertheless beneficiaries of the fact that it had succeeded. To recall that their nationality, their upbringing and their entitlements as citizens resulted from the outcome of these historical events, is not to question the seriousness of their cultural endeavours, but it is a context that should not be neglected.

The cultural memory of natural affection both reveals and conceals, concealing not least Pākehā desires to make the past better, justify settler status and naturalize belonging in the face of increasing Māori counter-claims. From the 1970s, racial amalgamation's child, the ideology of racial harmony, became increasingly unsustainable under the pressure of critique by both Māori and Pākehā. It is striking, however, that interracial plots have continued to recur as central elements throughout the corpus of New Zealand Wars film and fiction. ${ }^{64}$ Interracial intimacy persists from the nineteenth century to the twenty-first, as a complex but still constant companion to Pākehā cultural memory of colonial conflict in New Zealand.

\footnotetext{
${ }^{1}$ James Cowan, The New Zealand Wars: A History of the Maori Campaigns and the Pioneering Period, Wellington, 1983, II, pp.526-27. Colonial conflict in New Zealand first erupted in violent incidents in the 1840s, in Wairau and the Wellington and Hutt Valley area, and in Northland. The most widespread and longest conflicts, however, took place from 1860-1872, in a series of interrelated wars involving a number of tribes (iwi) right across the centre of the North Island. Incidents involving the invasion of Māori settlements by colonial troops and constabulary followed some decades later, in 1881 and 1916. These conflicts have played a varying part in the national historiography, produced at times as: shameful legacies for the settler population; evidence of an exciting national past; anomalous interruptions to predominantly peaceful settlement and happy intercultural relations; and events which defined the course of nation, or which exposed another dimension of nation more or less invisible to the now dominant Pākehā population. See, for example, James Belich, The New Zealand Wars and the Victorian Interpretation of Racial Conflict, Auckland,
} 
1986; Judith Binney, Redemption Songs: A Life of Te Kooti Arikirangi Te Turuki, Auckland, 1995; Cowan, The New Zealand Wars, II; G.W. Rusden, History of New Zealand, London, 1883; Dick Scott, The Parihaka Story, Auckland, 1954; Keith Sinclair, The Origins of the Maori Wars, 2nd ed., Wellington, 1961; Alan Ward, A Show of Justice: Racial 'Amalgamation' in Nineteenth Century New Zealand, Auckland, 1978.

${ }^{2}$ Angela Wanhalla, In/visible Sight: The Mixed-Descent Families of Southern New Zealand, Wellington, 2009; Damon I. Salesa, Racial Crossings: Race, Intermarriage, and the Victorian British Empire, Oxford, 2011; David Hackett Fischer, Freedom and Fairness: A History of Two Open Societies, New Zealand and the United States, New York, 2012.

${ }^{3}$ Avril Bell, 'Bifurcation or Entanglement? Settler Identity and Biculturalism in Aotearoa New Zealand', Continuum: Journal of Media \& Culture Studies, 20, 2 (2006), pp.253-68; and Belich, The New Zealand Wars.

${ }^{4}$ Edward Said, Culture and Imperialism, New York, 1993.

${ }^{5}$ Jacqueline Rose, States of Fantasy, Oxford, 1996.

${ }^{6}$ Wanhalla; Salesa.

7 ibid.

${ }^{8}$ James Belich, Paradise Reforged: A History of the New Zealanders from the $1880 \mathrm{~s}$ to the Year 2000, Auckland, 2001, p.191.

${ }^{9}$ See Ward, A Show of Justice; and for its implications for interracial marriage, Salesa.

${ }^{10}$ Salesa, pp.171-230.

${ }^{11}$ Belich, Paradise Reforged, p.191ff.

${ }^{12}$ Fitzgerald, 'Ake! Ake! Ake!' Press (Christchurch), 16 April 1864.

13 ibid.

${ }^{14}$ Memories of this event remain much more obscure and conflicting than those of Orākau. Tom Roa, interview by Annabel Cooper, 25 January 2011.

${ }^{15}$ Belich, Paradise Reforged, p.193.

${ }^{16}$ Belich, The New Zealand Wars; Salesa, ch.5.

${ }^{17}$ Belich, The New Zealand Wars.

${ }^{18}$ Michael King, The Penguin History of New Zealand, Auckland, 2003, pp.301-2;

Belich, Paradise Reforged, pp.192-2.

${ }^{19}$ For example, Fitzgerald; William Satchell, The Greenstone Door, London, 1914.

${ }^{20}$ As noted in 'James Cowan: A Tribute by Alan Mulgan', foreword to James Cowan, Tales of the Maori Border, Wellington, 1944.

${ }^{21}$ James Cowan, The Old Frontier: Te Awamutu, the Story of the Waipa Valley, Te Awamutu, 1922, p.86.

${ }^{22}$ David Colquhoun, 'James Cowan', in The Dictionary of New Zealand Biography (DNZB), Vol. Three, 1901-1920, Auckland, 1996, pp.119-21; P.G. Gibbons, 'Henry Matthew Stowell', in Dictionary of New Zealand Biography, Vol. Three, pp.492-3. Of Eileen's father, Gibbons notes: ‘A licensed Māori-language interpreter, Henry Stowell was an interpreter in a more general sense, one of many nineteenth-century New Zealanders who were genuinely bicultural and who moved easily between and within Māori and Pākehā communities'.

${ }^{23}$ James Cowan, 'The White Slave', New Zealand Times, September-October 1906; James Cowan, The Adventures of Kimble Bent: A Wild Life in the New Zealand Bush, London, 1911.

${ }^{24}$ Cowan, New Zealand Wars, I, pp.365-6. 
${ }^{25}$ Cowan, The Old Frontier, p.84.

${ }^{26}$ Cowan, New Zealand Wars, vol. I, pp. 397-9.

${ }^{27}$ ibid., p.401.

${ }^{28}$ ibid., p.400.

${ }^{29}$ Cowan, New Zealand Wars, vol. II, p.273.

${ }^{30}$ ibid., p.502.

${ }^{31}$ Notably, but by no means only, Mona Tracey, Rifle and Tomahawk, London, 1927; Errol Braithwaite's trilogy The Flying Fish, London, 1964, The Needle's Eye, London, 1965, and The Evil Day, London, 1967; Geoff Murphy, dir., Utu, Glitteron, 1983.

${ }^{32}$ Bruce Babington, 'Fifty Years a Pioneer: The Cinema of Rudall Hayward 19211972', in Bruce Babington, A History of the New Zealand Fiction Feature Film, Manchester, 2007, p.57.

${ }^{33}$ Rewi's Last Stand: An Episode of the New Zealand Wars, Maori War Films, 1925; The Te Kooti Trail, 1927; Rewi's Last Stand/The Last Stand, 1940. Hayward recalls reading Cowan as a teenager, and in the radio interviews broadcast in the early 1960s, he several times states that Cowan's history of the wars and his history of the Waipa, The Old Frontier, provided all the material for his New Zealand Wars films. Rudall Hayward, interview by Walter Harris, Radio New Zealand 1960-1962, Ref: AO644, New Zealand Film Archive. The second Rewi was cut from 114 to 64 minutes. See 'Rewi's Last Stand', pamphlet produced for 50 ${ }^{\text {th }}$ Anniversary, n.d. [c.1987-1988], ARC3630.2, Te Awamutu Museum Archive (TAMA), Te Awamutu.

34 'The Story', press kit for Rewi's Last Stand, Maori War Films, 1925, New Zealand Film Archive (NZFA), Wellington.

${ }^{35}$ In line with his customary practice of creating a publicity 'handle to the film', Hayward collaborated with Frank Bodle, co-writer of the screenplay, on a serialized account which was syndicated in a number of newspapers.

${ }^{36}$ Martin Blythe, Naming the Other: Images of the Maori in New Zealand Film and Television, Metuchen, 1994, pp.38-39; Alistair Fox, 'Rudall Hayward and the Cinema of Maoriland: Genre-Mixing and Counter-discourses in Rewi's Last Stand (1925), The Te Kooti Trail (1927) and Rewi's Last Stand/The Last Stand (1940)', in Alistair Fox, Barry Keith Grant and Hilary Radner, eds, New Zealand Cinema: Interpreting the Past, Bristol, 2011, pp.45-64.

${ }^{37}$ Blythe, pp.38-39.

${ }^{38}$ Diane Pivac, 'The Rise of Fiction: Between the Wars', in Diane Pivac, ed., New Zealand Film: An Illustrated History, Wellington, 2011, p.69; Babington, p.73.

${ }^{39}$ Babington.

40 'The big half-caste Peka Makarini, who fell to Mair's carbine, was a man with an atrocious record. It was estimated that he had been guilty of over thirty murders.' Cowan, New Zealand Wars, II p.395. For Pou-patate, see Cowan, New Zealand Wars, I, p.396.

${ }^{41}$ For assistance with the following section I thank Diane Pivac for sharing her extensive knowledge of Hayward's practice, and of the development of his cultural education over the three New Zealand Wars films. See her 'The Rise of Fiction: Between the Wars'.

${ }^{42}$ Hayward, interview. Te Puea did however purchase a few shares in Frontier Films, the company that funded the second Rewi's Last Stand. See Frontier Films List of Shareholders at 27 July 1939, ARC3003.8, TAMA. She also supplied canoes, extras 
and the use of the Turangawaewae marae for sequences in that film. See 'Rewi's Last Stand', pamphlet produced for $50^{\text {th }}$ Anniversary.

${ }^{43}$ Censor's decision on The Te Kooti Trail, 12 November 1927, MA1163, Folder

MANS.0013.01, NZFA.

${ }^{44}$ Pivac, p.69.

45 'Project to reproduce picture in sound', Waipa Post (WP), 8 June 1937, p.4;

'Talking picture being produced - Orakau siege', WP, 1 Oct 1937, p.5. Hayward, interview.

${ }^{46}$ This is not easy to establish without tracking the genealogy of each member.

European names certainly outnumber Māori names, but this had been an extensively intermarried community. 'E. Thomson', for example, is identified as one of the Society's Māori members.

${ }^{47}$ Minute Books of the Te Awamutu Historical Society, Te Awamutu Museum, 19371940, TAMA.

${ }^{48}$ Frontier Films' prospectus noted that 'To ensure the full co-operation of the members of the Maori people of this and surrounding districts, a Maori committee has been set up and the Committee assures the promoters that there will be no difficulty in obtaining the necessary numbers of Maoris from this district to amply represent the Chieftains, notable characters, and warriors of those historic times.' Frontier Films, Prospectus, filed 30 August 1937, ARC3003.9, TAMA.

${ }^{49}$ Years later, Te Rongonui Paerata's wife and daughter recalled that he had been so outraged at receiving only 'a pittance' for his part in the film that he had asked for footage including him to be removed. Huia Priestly to Jennifer Evans, 30 March 1993, ARC3630.1, TAMA. Some cast lists include the name of another actor, Henare Toka, who may have replaced him for some or all of the part.

${ }^{50}$ Hayward, interview. Emphasis added.

${ }^{51}$ Tom Roa, a senior Ngāti Maniapoto kaumatua, conveyed to me that even in 2011 the complex situations of individuals in interracial families is remembered. Roa, interview.

${ }^{52}$ Roa, interview; Salesa, ch.5.

${ }^{53}$ For example, 'A Maori Maiden and Her Admirers', Evening Post, 22 February 1865, p.3; cit. Cowan, The Old Frontier, pp.81-83.

${ }^{54}$ Hayward, interview.

${ }^{55}$ Salesa, ch.5.

${ }^{56}$ Roa, interview; Salesa, ch.5. Judith Binney notes that the expulsions were 'in retaliation for the government's requirement that Waikato Māori leave Auckland, the capital'. See Judith Binney, 'In-Between' Lives: Studies from within a colonial society', in Tony Ballantyne and Brian Moloughney, eds, Disputed Histories: Imagining New Zealand's Pasts, Dunedin, 2006, p.96.

${ }^{57}$ This character is prefigured in the silent Rewi in the historically-based character of McDonnell, who has been brought up among Ngāpuhi and handles a taiaha well.

${ }^{58}$ That this is intended is clear from the original synopsis of the uncut film. See 'Brief synopsis of the film "Rewi's Last Stand", ARC1265, TAMA.

${ }^{59}$ Hayward and Reed, Rewi's Last Stand, Wellington, 1944, pp.147-8.

${ }^{60}$ William Pember Reeves, The Long White Cloud: Ao Tea Roa, London, 1898; Satchell; Mona Tracey, Rifle and Tomahawk: A Stirring Tale of the Te Kooti Rebellion, London, 1927.

${ }^{61}$ Alex Calder discusses this pattern in fiction in his The Settler's Plot: How Stories Take Place in New Zealand, Auckland, 2011. 
${ }^{62}$ Binney, “In-Between' Lives'; see also Cowan's accounts of James Edwards and John Gage in his New Zealand Wars, I, p.351, and of Lucy Takiora, p.206.

${ }^{63}$ Hazel Riseborough, Days of Darkness: Taranaki, 1878-1884, Auckland, 2002;

Danny Keenan, Wars Without End: The land wars in nineteenth-century New

Zealand, Auckland, 2009.

${ }^{64}$ See Utu; Maurice Shadbolt's trilogy of novels on the New Zealand Wars, Season of the Jew, London, 1986; Monday's Warriors, Auckland, 1990; The House of Strife, Auckland, 1993; and Vincent Ward's feature film River Queen, 2005. 